\title{
INFLUENCE OF SINTERING TEMPERATURE ON NiO-SDCC ANODE FOR LOW-TEMPERATURE SOLID OXIDE FUEL CELLS (LT-SOFCs)
}

\author{
LILY SIONG MAHMUD, \#ANDANASTUTI MUCHTAR, MAHENDRA RAO SOMALU \\ Fuel Cell Institute, Universiti Kebangsaan Malaysia, 43600 UKM Bangi, Selangor, Malaysia \\ "E-mail: muchtar@ukm.edu.my
}

Submitted May 31, 2016; accepted July 27, 2016

\begin{abstract}
Keywords: SOFCs, Composite, NiO-SDCC anode, Microstructures, Sintering
The effects of sintering temperature on the microstructural and physical properties of NiO-SDCC anode pellets are evaluated in this study. Composite powders of NiO-SDCC (nickel oxide, samarium-doped ceria, $\mathrm{Sm}_{0.2} \mathrm{Ce}_{0.8} \mathrm{O}_{1.9}$ ) mixed with binary carbonates (67 mol. \% $\mathrm{Li}_{2} \mathrm{CO}_{3}$ and $33 \mathrm{~mol} . \% \mathrm{Na}_{2} \mathrm{CO}_{3}$ ) was prepared, ball-milled, and oven-dried. Carbon black and polyethylene glycol were added to the NiO-SDCC powders as pore former and binder, respectively, to fabricate NiO-SDCC pellets. This mixture was then pressed onto a cylindrical mold under a pressure of $32 \mathrm{MPa}$. The pellets were subsequently sintered at 600,700, 800, 900 and $1000^{\circ} \mathrm{C}$ for $2 \mathrm{~h}$. Phase transformation, particle size, morphology, and specific surface area (SBET) of the NiO-SDCC composite powder were investigated. Porosity and microstructure of the NiO-SDCC anode pellets were then evaluated after sintering. Results showed that the porosities of the NiO-SDCC pellets decreased as the sintering temperature increased. The increments of sintering temperature reduced the porosity of the pellets, but NiO-SDCC pellets sintered at $800^{\circ} \mathrm{C}$ exhibited an acceptable porosity of $32.60 \%$. Furthermore, surface images showed that the microstructures of sintered pellets at $800^{\circ} \mathrm{C}$ were well-bonded and kept a uniform particle size distribution.
\end{abstract}

\section{INTRODUCTION}

Research and development of solid oxide fuel cells (SOFCs) have focused significant attention to reducing the operating temperature of the cells. Anode-supported SOFCs with a planar configuration are generally favoured over electrolyte-supported SOFCs because of low operating temperatures, thereby reducing manufacturing costs and widening the choice of materials [1-3]. Furthermore, anode-supported cells are more reliable, stable, and able to reduce the electrolyte thickness and resistance between electrolyte interfaces [4-6].

The performance of an anode-supported SOFC is normally governed by anode properties, such as gas permeability, mechanical stability, electrical conductivity, and electrochemical catalytic activity [7, 8]. Anode microstructural properties, such as porosity and pore size distribution should be controlled and improved after sintering process to enhance the performance of anode-supported SOFCs [9, 10]. Moreover, porosity is one of the significant factors that can influence triplephase boundary (TPB) density $[11,12]$. Electrochemical reactions can only occur at the ТPB when the oxygen ion conductor (the electrolyte), the electron-conducting metal phase, and the gas phase come into contact with each other. Optimization of the anode microstructure by decreasing the particle size and enhancing the surface area must be achieved to improve TPB expansion $[13,14]$.
Therefore, selecting a sufficient sintering temperature is important to control the growth of the particle size of the anode-supported SOFC. Several researchers have investigated the effects of sintering temperatures on supported structures in different aspects. Liu et al. [10] analyzed the effects of different sintering temperatures on the particle size distributions and grain growth activation energies of NiO-YSZ anodes. Shimada et al. [9] investigated the influences of sintering temperatures and pore formers (mixture of graphite carbon and cellulose) on NiO-YSZ. They determined that the NiO-YSZ anode substrate with 33.8 wt. \% pore former and sintered at $1350^{\circ} \mathrm{C}$ exhibited a high porosity and a uniform pore size distribution. This cell had also minimized the concentration polarization resistance and gained a maximum power density of $3.09 \mathrm{~W} \cdot \mathrm{cm}^{-2}$ at $800^{\circ} \mathrm{C}$.

Ni-YSZ, Ni-GDC, Ni-CGO, and Ni-SDC cermet composite powders have been previously used as anode substrates; however, all these anode materials are operated at high and intermediate temperatures $[15,16]$. Only a few studies on anode-supported SOFCs operating at low temperatures have been conducted. Samariumdoped cerium oxide (SDC) mixed with lithium carbonate $\left(\mathrm{Li}_{2} \mathrm{CO}_{3}\right)$ and sodium carbonate $\left(\mathrm{Na}_{2} \mathrm{CO}_{3}\right)$ has potential as composite electrolyte for SOFCs operating at less than $600^{\circ} \mathrm{C}$ [17-19]. Jarot et al. [20] reported that NiO-SDC (C-carbonates) can be used as SOFC anode substrate at low operating temperatures $\left(<600^{\circ} \mathrm{C}\right)$. Therefore, the 
present research focuses on the development of $\mathrm{NiO}$ SDCC anodes for anode-supported SOFC application. Carbon black was used as the pore former in the fabrication of anode substrates. The characteristics of the anodes, such as phase, porosity, microstructure, surface area, and particle size, were investigated as functions of sintering temperatures in this study.

\section{EXPERIMENTAL}

Preparation of anode composite materials

Binary carbonates consisting of $67 \mathrm{~mol} . \% \mathrm{Li}_{2} \mathrm{CO}_{3}$ (R\&M Marketing, Essex, UK) and 33 mol. \% $\mathrm{Na}_{2} \mathrm{CO}_{3}$ (Friedemann Schmidt Chemical) were prepared. SDC $\left(\mathrm{Sm}_{0.2} \mathrm{Ce}_{0.8} \mathrm{O}_{1.9}\right)$ and carbonate $\left(\mathrm{Li}_{2} \mathrm{CO}_{3}\right.$ and $\left.\mathrm{Na}_{2} \mathrm{CO}_{3}\right)$ powders were weighed to a ratio of 8:2. This mixture was ball-milled at $200 \mathrm{rpm}$ for $16 \mathrm{~h}$ in ethanol with $\mathrm{ZrO}_{2}$ balls (diameter of $5 \mathrm{~mm}$ ) in a zirconia bowl $\left(250 \mathrm{~cm}^{3}\right)$. The ratio of powder to $\mathrm{ZrO}_{2}$ balls was $4: 1$ [21]. After milling, the mixture was oven-dried at $120^{\circ} \mathrm{C}$ for $12 \mathrm{~h}$ to evaporate the ethanol and calcined at $680^{\circ} \mathrm{C}$ for $1 \mathrm{~h}$ at a heating rate of $10^{\circ} \mathrm{C} \cdot \mathrm{min}^{-1}$ to obtain pure SDC with carbonate powders $[18,20]$. The produced SDCC powder was ground in an agate mortar to a fine powder with reduced agglomeration. Then, 60 wt. \% NiO (99.8\% purity with particle size of $<50 \mathrm{~nm}$; Sigma-Aldrich) and 40 wt. \% SDCC were mixed and ball-milled under the conditions applied to the SDCC powder to obtain the NiO-SDCC anode composite powder. The obtained mixture was then oven-dried at $90^{\circ} \mathrm{C}$ for $24 \mathrm{~h}$ and sieved through $212 \mu \mathrm{m}$ woven wire to obtain a fine and uniform powder.

Next NiO-SDCC composite powder was mixed with polyethylene glycol (as binder) and carbon black $1.6 \mathrm{wt}$ \% (as pore former) using an agate mortar to prepare the anode-supported green pellets $[11,22]$. The mixture was then ground and sieved through $212 \mu \mathrm{m}$ woven wire to obtain a fine powder. The mixed powder (1.6 g) was uniaxially dry-pressed into circular pellets with diameters of $25 \mathrm{~mm}$ under a pressure of $32 \mathrm{MPa}$. The approximate thickness of each dry-pressed pellet was less than $1 \mathrm{~mm}$. The pellets were sintered at $600^{\circ} \mathrm{C}$, $700^{\circ} \mathrm{C}, 800^{\circ} \mathrm{C}, 900^{\circ} \mathrm{C}$, and $1000^{\circ} \mathrm{C}$ in air for $2 \mathrm{~h}$ at a heating rate of $2^{\circ} \mathrm{C} \cdot \mathrm{min}^{-1}$ to investigate the effects of different sintering temperatures.

\section{Characterization of composite powders and pellets}

The crystalline and structure phases of the powder were examined by X-ray diffraction (XRD; Bruker AXS Germany, D8 Advance) using $\mathrm{Cu} \mathrm{K} \alpha$ radiation $(\lambda=0.15406 \mathrm{~nm})$ with the operating voltage and current of $40 \mathrm{kV}$ and $40 \mathrm{~mA}$, respectively. The scanning range varied between $10^{\circ}$ and $100^{\circ}$, with a step size of $0.025^{\circ}$ and a counting rate of $0.1 \mathrm{~s}$ per scanning step. The morphologies of the NiO-SDCC powders and sintered pellets were observed via field emission scanning electron microscope (FESEM; Zeiss Supra-55VP). Brunauer-Emmett-Teller (BET; Micromeritics ASAP 2020) analysis with nitrogen physisorption at $-195.8^{\circ} \mathrm{C}$ was used to measure the specific surface area $\left(S_{\mathrm{BET}}\right)$ of the powders. Particle sizes and powder distributions were analyzed by a laser scattering technique (Malvern Instruments, Zetasizer Nanoseries). Deionized water was mixed with the powders as a dispersant, and the resulting mixture was sonicated for $30 \mathrm{~min}$ prior to measurement. The porosity of these anode pellets was evaluated using the standard Archimedes method.

\section{RESULTS AND DISCUSSION}

\section{Characteristics of NiO-SDCC composite powders}

Figure 1 displays the XRD patterns of the SDCC mixture. The raw SDC powders showed a crystallite size of $433.2 \AA$ and a single cubic phase (space group Fm-3m). Mixing the carbonate powders $\left(\mathrm{Li}_{2} \mathrm{CO}_{3}\right.$ and $\mathrm{Na}_{2} \mathrm{CO}_{3}$ ) into the SDC powders did not alter the observed phase, but increased the crystallite size of the prepared SDCC powder to $507.0 \AA$. Meanwhile the XRD patterns of the NiO-SDCC mixture are shown in Figure 2. In the $\mathrm{NiO}-\mathrm{SDCC}$ composite powder, the crystallite size of the $\mathrm{NiO}$ powders increased from $105.5 \AA$ to $132.0 \AA$ and presented a cubic phase (lattice parameter $a=4.18443 \AA$ ). However, the crystallite size of SDCC decreased to $484.0 \AA$ and maintained a cubic phase (lattice parameter $a=5.43319 \AA$ ). No remarkable secondary constituents were observed in the NiO-SDCC composite powder within the sensitivity of the XRD instrument, which is consistent with other studies [23, 24].

Figure $3 \mathrm{a}$ shows the morphology of raw SDC powder, and Figure $3 \mathrm{~b}$ shows the morphology of the

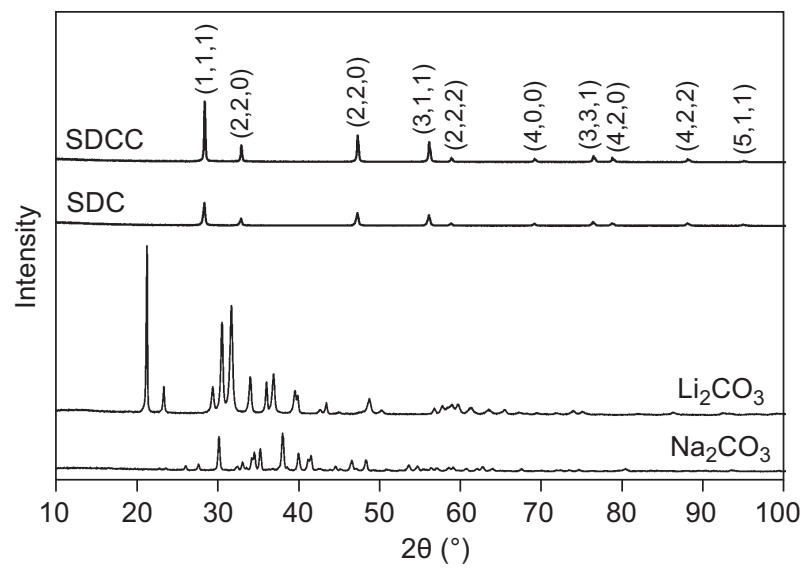

Figure 1. XRD patterns of $\mathrm{Na}_{2} \mathrm{CO}_{3}, \mathrm{Li}_{2} \mathrm{CO}_{3}, \mathrm{SDC}$ and the SDCC composite powders. 


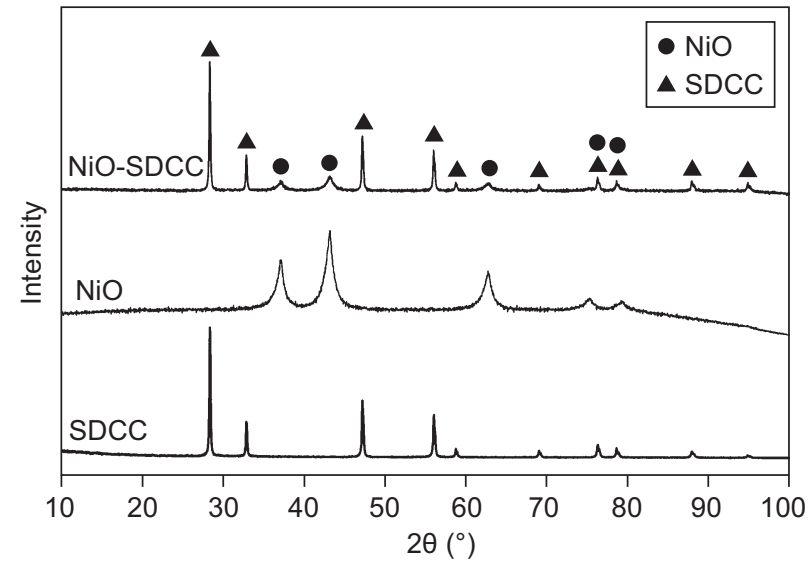

Figure 2. XRD patterns of SDCC, NiO and the NiO-SDCC composite powders.

SDCC composite powders after calcination. After calcination, the morphology of SDCC particles were homogenous with amorphous microstructures and the particles were coated with carbonates. Such morphology increases the ionic conductivity of electrolytes [20, 25]. Moreover, energy-dispersive X-ray spectroscopy (EDX) analysis of SDCC powders shown in Figure 3e

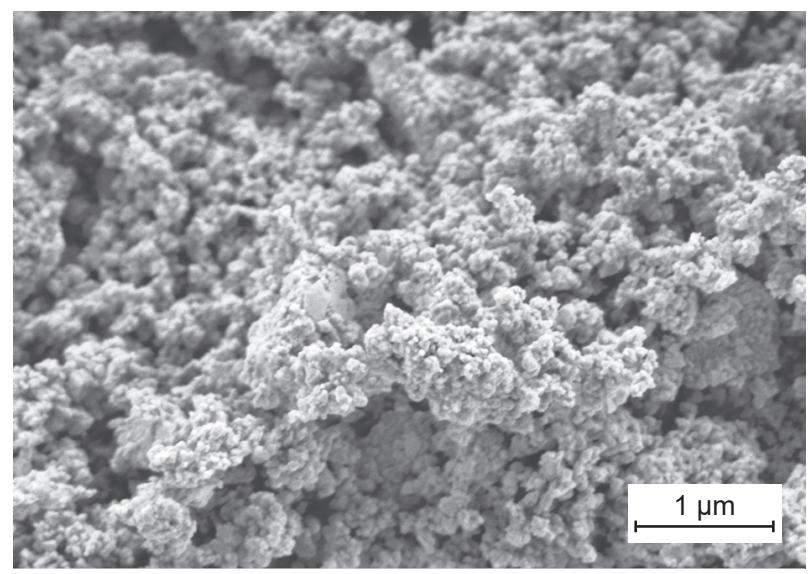

a) $\mathrm{SDC}$

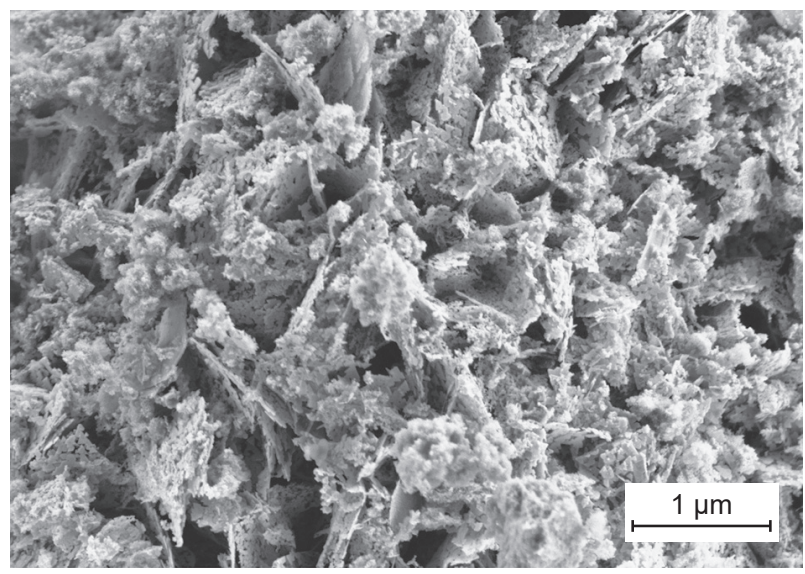

c) $\mathrm{NiO}$ revealed the existence of carbonates in these composite powders, although only $20 \mathrm{wt}$. $\%$ of carbonates were added into the SDC.

The morphology of the NiO-SDCC powder shown in Figure 3d illustrates that the SDCC grains interacted well with the $\mathrm{NiO}$ grains and were homogenous, compared with the raw $\mathrm{NiO}$ powder, as illustrated in Figure 3c. This morphology led to the increment of the NiO-SDCC surface area by $27.82 \mathrm{~m}^{2} \cdot \mathrm{g}^{-1}$, compared with the surface area value in a previous study [23]. The increase in surface area is necessary to improve the gas diffusion channels in the anode and, consequently, to enlarge the TPB density of the anode $[9,26]$. EDX analysis shown in Figure $3 \mathrm{f}$ revealed that $\mathrm{NiO}, \mathrm{SDC}$, and carbonates existed in these composite powders after the solid-state reaction process.

Figure 4 shows the particle size distributions of $\mathrm{SDC}, \mathrm{SDCC}, \mathrm{NiO}$, and NiO-SDCC composite powders. After mixing the SDC powder with the carbonates, the average particle size of SDCC increased to $676 \mathrm{~nm}$, compared with the size of commercial SDC powders $(279.8 \mathrm{~nm})$. This increment is consistent with the reduction in the surface area of $\operatorname{SDCC}\left(3.98 \mathrm{~m}^{2} \cdot \mathrm{g}^{-1}\right)$,

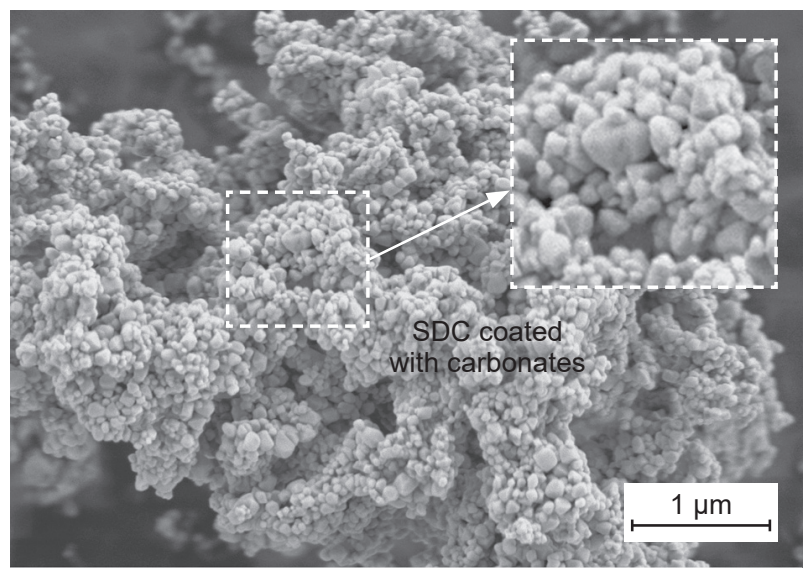

b) SDCC

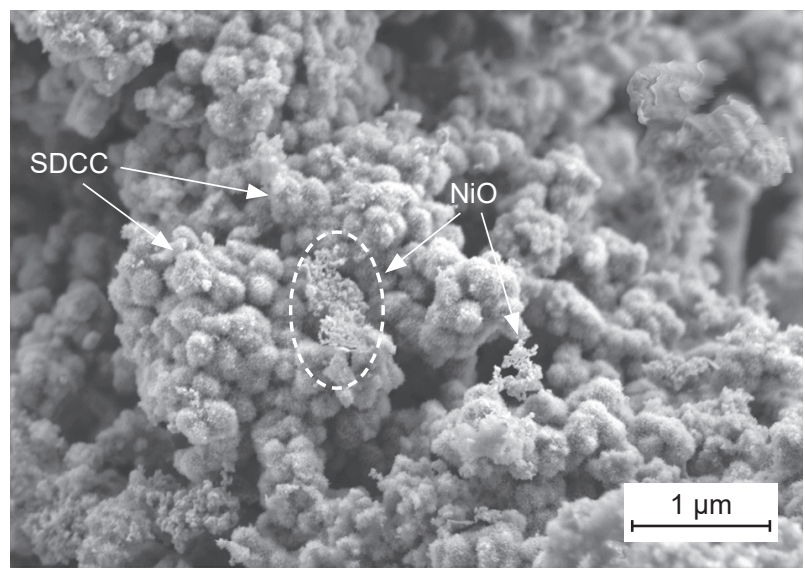

d) NiO-SDCC

Figure 3. Powder morphologies of: a) SDC, b) SDCC, d) NiO-SDCC and e) SDCC and EDX analyses of composite powders: c) $\mathrm{NiO}$ and $\mathrm{f}$ ) NiO-SDCC. (Continue on next page)

Ceramics - Silikáty 60 (4) 317-323 (2016) 
Mahmud L. S., Muchtar A., Somalu M. R.

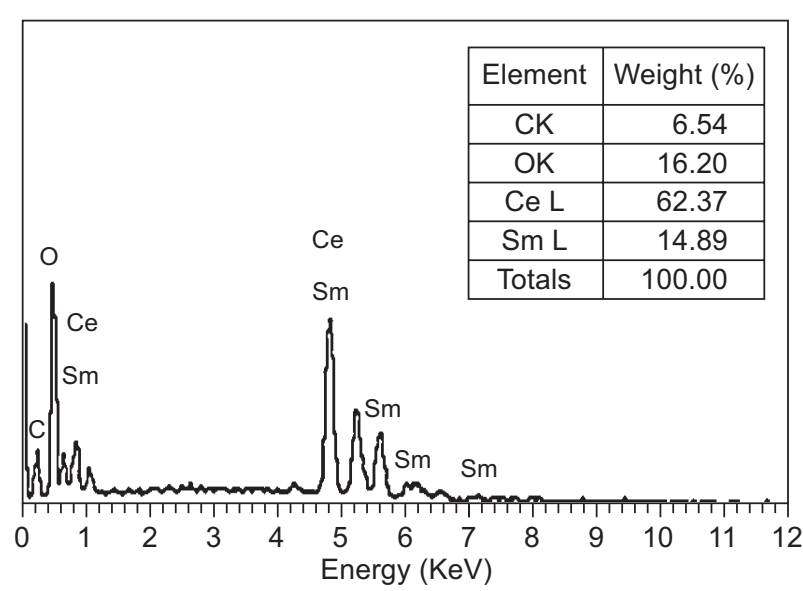

e) SDCC

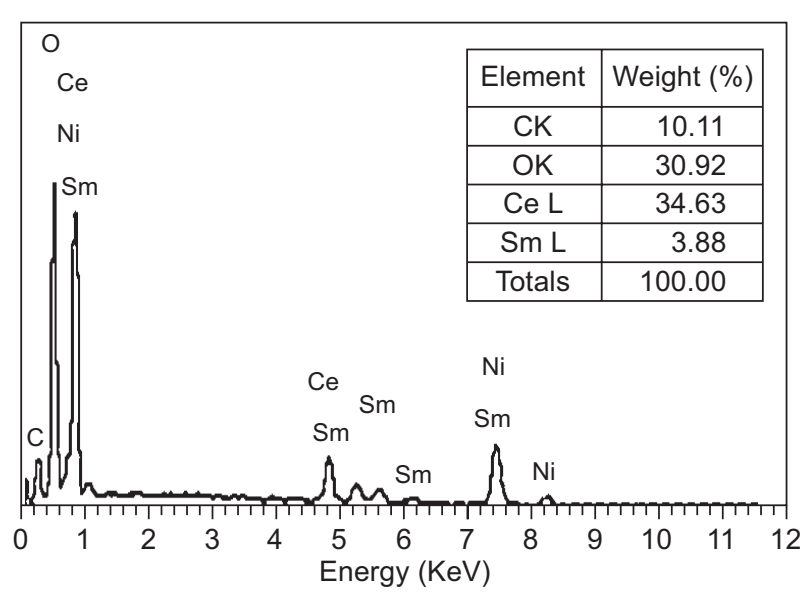

f) $\mathrm{NiO}-\mathrm{SDCC}$

Figure 3. Powder morphologies of: a) SDC, b) SDCC, d) NiO-SDCC and e) SDCC and EDX analyses of composite powders: c) $\mathrm{NiO}$ and f) $\mathrm{NiO}-\mathrm{SDCC}$.

compared with surface area of SDC powder $\left(9.45 \mathrm{~m}^{2} \cdot \mathrm{g}^{-1}\right)$. This decrease is a result of carbonate melting and flowing onto the surface of the SDC grains during calcination [19, 20]. The particle size distribution of $\mathrm{NiO}$ raw powder (average particle size of $0.613 \mu \mathrm{m}$ ) is consistent with that of NiO-SDCC composite powder. Mixing of SDCC powder into $\mathrm{NiO}$ powder had increased the particle size of NiO-SDCC in the range of $0.1 \mu \mathrm{m}$ to $5 \mu \mathrm{m}$, as a result of agglomeration, as shown in Figure 3. However, the average particle size of $\mathrm{NiO}-\mathrm{SDCC}$ composite powder remains in the submicron level.

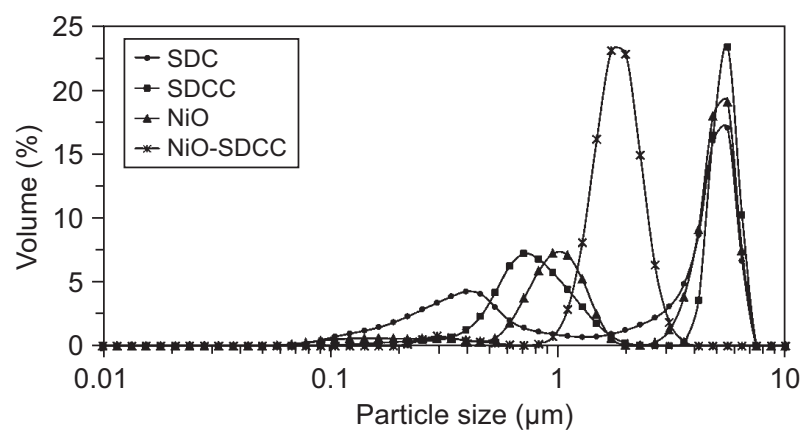

Figure 4. Particle size distribution of SDC, SDCC, NiO and NiO-SDCC powders.

Microstructure and porosity of $\mathrm{NiO}-\mathrm{SDCC}$ anode pellets

The presence of pores among grains in the NiOSDCC anode pellets can be clearly seen in the FESEM surface images shown in Figure 5. These pellets were sintered at $600,700,800,900$ and $1000{ }^{\circ} \mathrm{C}$. Carbon black was used as the pore former in the anode composite powder to sustain a uniform distribution of porosity in the pellet during high sintering temperatures. The particle size of NiO-SDCC appeared to increase with the sintering temperature. Under the same conditions, as the particle grain size increased, the porosity of the pellets decreased with the increase in the sintering temperature. For pellets sintered at $600^{\circ} \mathrm{C}$, the surface morphology shown in Figure 5a revealed that these particles had fewer connections, compared with the pellets that had been sintered above $600^{\circ} \mathrm{C}$. The surface morphologies of pellets sintered at $700^{\circ} \mathrm{C}$ and $800^{\circ} \mathrm{C}$ shown in Figures $5 \mathrm{~b}$ and $5 \mathrm{c}$ revealed good bonding between the particles and a uniform particle size distribution and pore size. These properties improved gas diffusion during the electrochemical test [11]. Grain growth increased with the increase in sintering temperature, particularly in pellets sintered at $900^{\circ} \mathrm{C}$ and $1000^{\circ} \mathrm{C}$, as shown in Figures $5 \mathrm{~d}$ and $5 \mathrm{e}$, respectively.

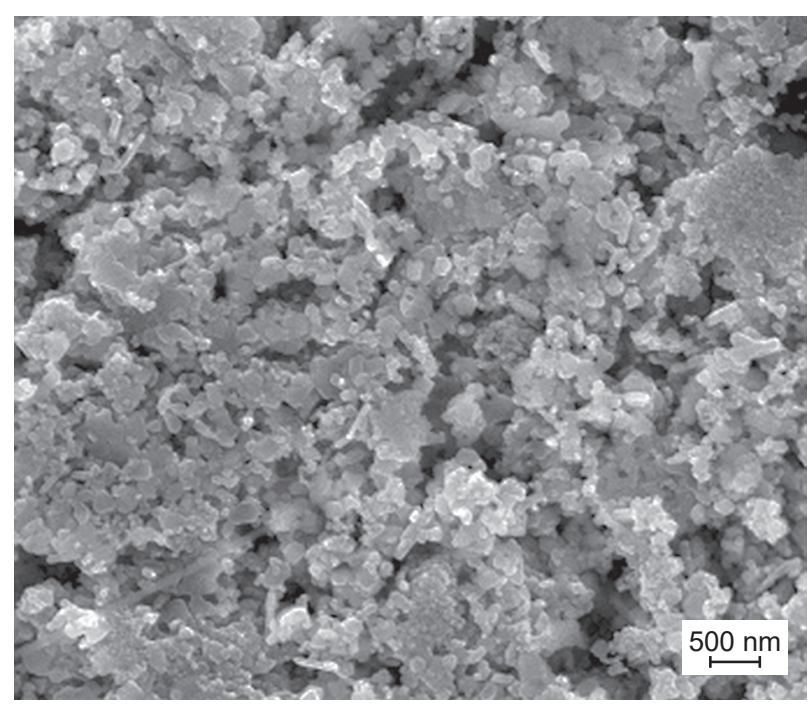

a) $600{ }^{\circ} \mathrm{C}$

Figure 5. FESEM surface images of NiO-SDCC anode pellets sintered in air at five different temperatures: a) $600^{\circ} \mathrm{C}$. (Continue on next page) 


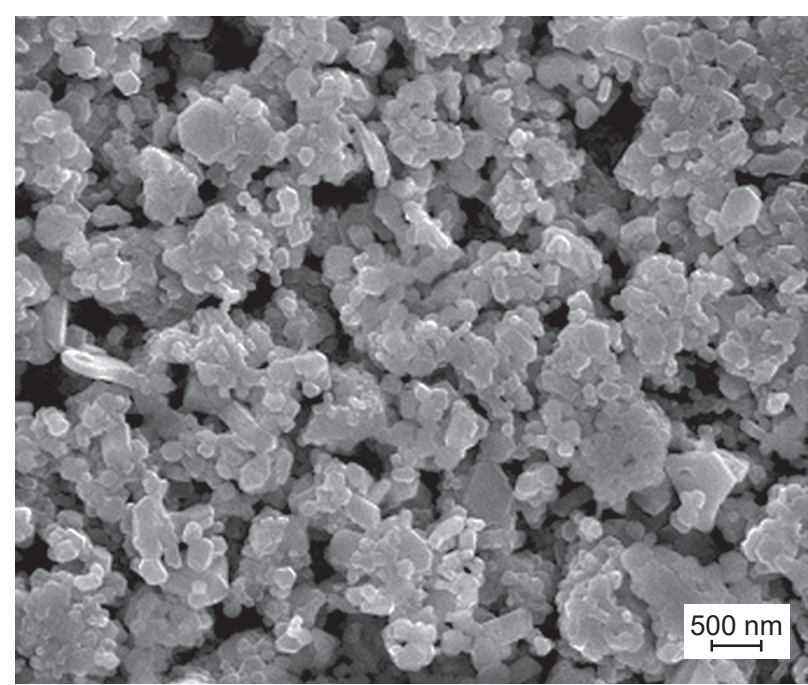

b) $700{ }^{\circ} \mathrm{C}$

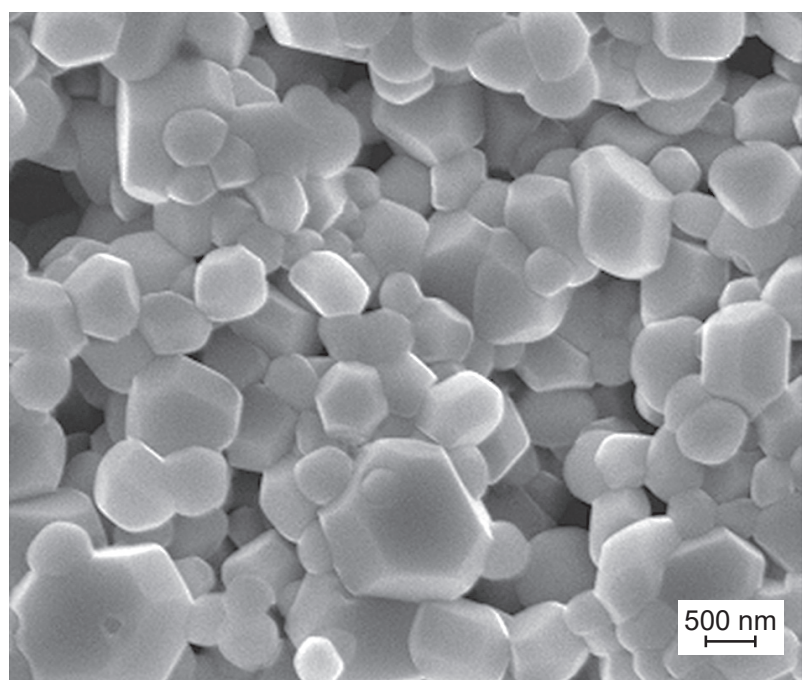

d) $900{ }^{\circ} \mathrm{C}$

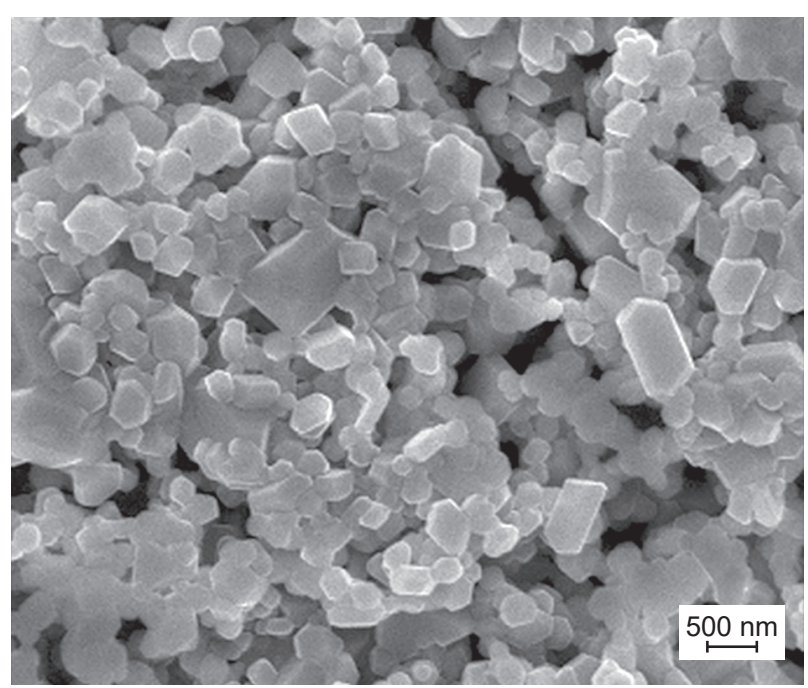

c) $800{ }^{\circ} \mathrm{C}$

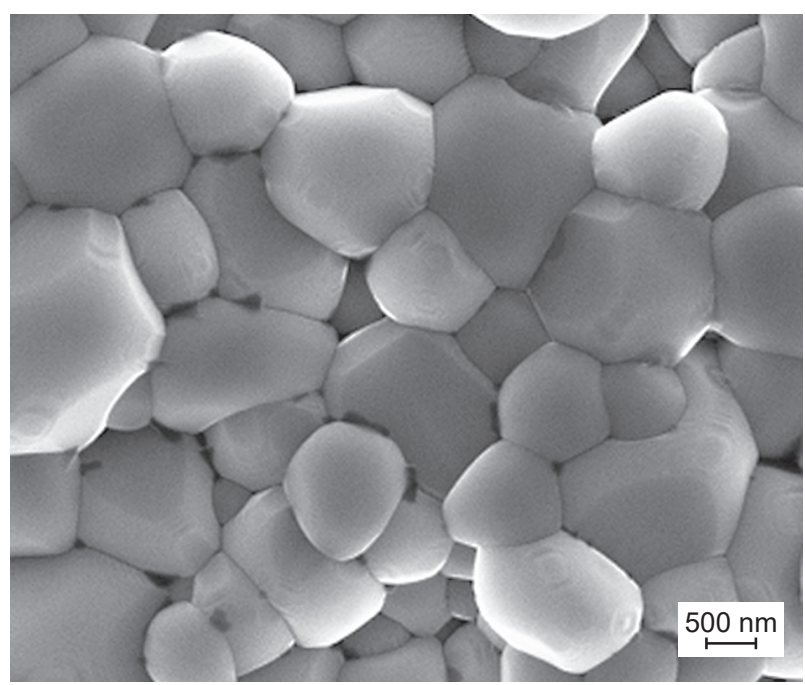

e) $1000^{\circ} \mathrm{C}$

Figure 5. FESEM surface images of NiO-SDCC anode pellets sintered in air at five different temperatures: b) 700, c) 800 , d) 900 and e) $1000^{\circ} \mathrm{C}$.

The morphology of the anode pellets was consistent with the porosity determined via the standard Archimedes method, as shown in Figure 6. The open porosity of each anode pellet decreased with the increase in sintering temperature. The pore size and distribution of sintered pellets at $1000^{\circ} \mathrm{C}$ significantly decreased and became nearly unnoticeable, as illustrated in Figure 5e. Pellets sintered at $600,700,800,900$ and $1000^{\circ} \mathrm{C}$ exhibited porosities of $43.92,41.54,32.60,24.38$ and $23.16 \%$, respectively. The anode support must feature approximately $30 \%$ to $40 \%$ porosity to maximize the oxidation reaction $[5,27,28]$. Thus, the pellets sintered at $800^{\circ} \mathrm{C}$ with a porosity of approximately $32.60 \%$, as estimated from their volume and weight, can be used as support structure for SOFC single cells. Meanwhile, the porosity of pellets sintered at 900 and $1000^{\circ} \mathrm{C}$ decreased by approximately $10 \%$, compared with that of pellets sintered at $800^{\circ} \mathrm{C}$. This condition occurred because the pores of the pellets were covered by the carbonates when the pellets were sintered at a temperature above the melting point of carbonates [19]. Insufficient porosity may limit the catalytic activity of the anode during the electrochemical performance test. Therefore, the addition of carbon black as the pore former in the NiOSDCC pellets is considerably important to improve the porosity of anodes [22, 29].

Porous structures were homogeneous in pellets sintered at 700,800 and $900^{\circ} \mathrm{C}$, as shown in Figure 5 . However, mechanical failure and decreased durability may occur if the supporting structure is too porous, as in anode-supported pellets sintered at $600^{\circ} \mathrm{C}$ and $700^{\circ} \mathrm{C}$, with porosity percentages of more than $40 \%$. In this regard, further investigation is required to evaluate the mechanical strength and durability of the reduced Ni-SDCC anode samples as a function of sintering temperature. 
Mahmud L. S., Muchtar A., Somalu M. R.

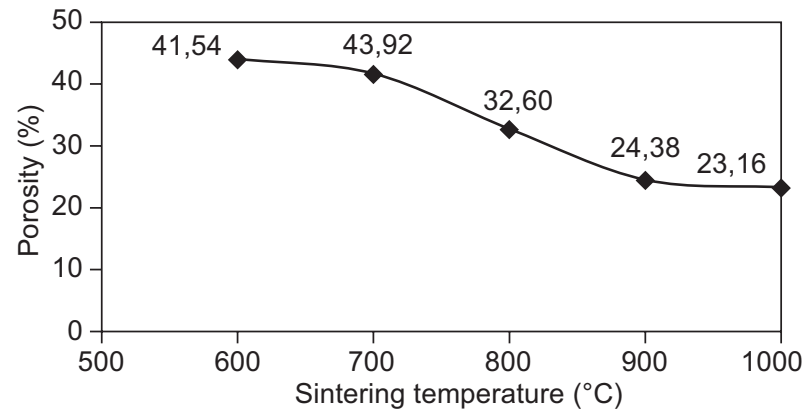

Figure 6. Variation of porosity as a function of the sintering temperature of the NiO-SDCC anode-supported pellets.

\section{CONCLUSIONS}

The microstructural properties of the supporting structures are crucial for the performance of SOFC single cells. The addition of SDCC as a catalyst for anode-supported cells changed the properties of $\mathrm{NiO}$. The coarse grains of $\mathrm{NiO}$ and SDCC powders were mixed homogeneously with carbon black as the pore former via ball-milling. The morphology of the resulting NiO-SDCC powders showed good interaction and less particle agglomeration than the raw $\mathrm{NiO}$ powders. NiOSDCC composite powders were dry-pressed into anodesupported pellets with a minimum thickness of less than $1 \mathrm{~mm}$ and sintered at five different temperatures from $600^{\circ} \mathrm{C}$ to $1000^{\circ} \mathrm{C}$. The FESEM image of the anodesupported pellets sintered at $800^{\circ} \mathrm{C}$ showed good bonding between the particles, with an acceptable level of anode porosity $(32.60 \%)$. Therefore, NiO-SDCC anode pellets sintered at $800^{\circ} \mathrm{C}$ can be used as supporting structures for low-temperature SOFC single cells. Hardness tests can be conducted in the future to measure the mechanical strength of anode-supported materials before the fabrication of SOFC single cells.

\section{Acknowledgements}

This work was supported by the Universiti Kebangsaan Malaysia (UKM) and the Ministry of Science, Technology and Innovation, Malaysia, via research grants FRGS/2/2013/TK06/UKM/02/9 and 03-01-02-SF1079, respectively. The authors would like to acknowledge the support of the Centre for Research and Instrumentation Management, UKM, for providing excellent testing equipment. The first author would also like to acknowledge the Malaysian Ministry of Higher Education for supporting her graduate studies.

\section{REFERENCES}

1. Minh N. Q. (2004): Solid oxide fuel cell technologyfeatures and applications. Solid State Ionics, 174, 271-277. doi:10.1016/j.ssi.2004.07.042
2. Seok C., Moon J., Park M., Hong J., Kim H., Son J. W., Lee J. H., Kim B. K., Lee H. W., Yoon K. J. (2016): Lowtemperature co-sintering technique for the fabrication of multi-layer functional ceramics for solid oxide fuel cells. Journal of the European Ceramic Society, 36, 1417-1425. doi:10.1016/j.jeurceramsoc.2015.12.029

3. Sun H., Zhang Y., Gong H., Li Q., Bu Y., Li T. (2016): Anode-supported SOFCs based on $\mathrm{Sm}_{0.2} \mathrm{Ce}_{0.8} \mathrm{O}_{2-\delta}$ electrolyte thin-films fabricated by co-pressing using microwave combustion synthesized powders. Ceramics International, 42, 4285-4289. doi:10.1016/j.ceramint.2015.11.105

4. Haanappel V. (2012). Advances in solid oxide fuel cell development between 1995 and 2010 at Forschungszentrum Jülich GmbH, Germany, in: Stolten D., Emonts B. (Ed.): Fuel cell science and engineering. Wiley-VCH Verlag $\mathrm{GmbH} \&$ Co. KGaA. pp. 247-274. doi:10.1002/9783527650248.ch9

5. Huang K., Goodenough J.B. (2009). Solid oxide fuel cell technology: Principles, performance and operations. Woodhead Publishing Limited and CRC Press LLC.

6. Bozorgmehri S., Hamedi M. (2013): Analysis of design parameters in anode-supported solid oxide fuel cells using response surface methodology. Fuel Cells, 13, 751-760. doi:10.1002/fuce.201300046

7. Singhal S. C., Kendall K. (2003). High temperature solid oxide fuel cells: Fundamentals, design and application. Elsevier Advanced Technology.

8. Ettler M., Menzler N. H., Mauer G., Tietz F., Buchkremer H. P., Stover D. (2011). Strategies to Improve the Reliability of Anode-Supported Solid Oxide Fuel Cells with Respect to Anode Reoxidation, in: Sundaram S. K., Fox K., Ohji T., Hoffman E. (Ed.): Advances in Materials Science for Environmental and Nuclear Technology II. John Wiley \& Sons, Inc. pp. 101-110. doi:10.1002/9781118144527.ch11

9. Shimada H., Suzuki T., Yamaguchi T., Sumi H., Hamamoto K., Fujishiro Y.(2016): Challenge for lowering concentration polarization in solid oxide fuel cells. Journal of Power Sources, 302, 53-60. doi:10.1016/j.jpowsour.2015.10.024

10. Liu S. S., Koyama M., Toh S., Matsumura S. (2014): Microstructure evolution of NiO-YSZ cermet during sintering. Solid State Ionics, 262, 460-464. doi:10.1016/j. ssi.2014.04.007

11. Chung M. A., Song J. H., Kang I., Sammes N. (2010). Characterization of an Anode-Supported Planar Solid Oxide Fuel Cell with a Porosity Concentration Gradient, in: Bansal N. P., Singh P. (Ed.): Advances in Solid Oxide Fuel Cells V. John Wiley \& Sons, Inc. pp. 75-81. doi:10.1002/9780470584316.ch6

12. Stambouli A. B., Traversa E. (2002): Solid oxide fuel cells: A review of an environmentally clean and efficient source of energy. Renewable and Sustainable Energy Reviews, 6, 433-455. doi: 10.1016/S1364-0321(02)00014-X

13. Liu Q., Dong X., Yang C., Ma S., Chen F. (2010): Selfrising synthesis of Ni-SDC cermets as anodes for solid oxide fuel cells. Journal of Power Sources, 195, 15431550. doi:10.1016/j.jpowsour.2009.09.071

14. Sun C., Stimming U. (2007): Recent anode advances in solid oxide fuel cells. Journal of Power Sources, 171, 247260. doi: 10.1016/j.jpowsour.2007.06.086

15. Shaikh S. P. S., Muchtar A., Somalu M. R. (2015): A review on the selection of anode materials for solid-oxide fuel cells. Renewable and Sustainable Energy Reviews, 51, 1-8. doi:10.1016/j.rser.2015.05.069 
16. Tarancón A. (2009): Strategies for Lowering Solid Oxide Fuel Cells Operating Temperature. Energies, 2, 1130. doi:10.3390/en20401130

17. Bodén A., Di J., Lagergren C., Lindbergh G., Wang C. Y. (2007): Conductivity of SDC and ( $\mathrm{Li} / \mathrm{Na})_{2} \mathrm{CO}_{3}$ composite electrolytes in reducing and oxidising atmospheres. Journal of Power Sources, 172, 520-529. doi:10.1016/j. jpowsour.2007.07.065

18. Muhammed Ali S. A., Muchtar A., Bakar Sulong A., Muhamad N., Herianto Majlan E. (2013): Influence of sintering temperature on the power density of samariumdoped-ceria carbonate electrolyte composites for lowtemperature solid oxide fuel cells. Ceramics International, 39, 5813-5820. doi:10.1016/j.ceramint.2013.01.002

19. Chen M., Zhang H., Fan L., Wang C., Zhu B. (2014): Ceria-carbonate composite for low temperature solid oxide fuel cell: Sintering aid and composite effect. International Journal of Hydrogen Energy, 39, 12309-12316. doi:10.1016/j.ijhydene.2014.04.004

20. Jarot R., Muchtar A., Wan Daud W. R., Muhamad N., Majlan E. H. (2010): Fabrication of dense composite ceramic electrolyte SDC-(Li/Na) 2Co3. Key Engineering Materials, 447, 666-670. doi:10.4028/www.scientific.net/ KEM.447-448.666

21. Somalu M. R., Yufit V., Cumming D., Lorente E., Brandon N. P. (2011): Fabrication and characterization of Ni/ScSZ cermet anodes for IT-SOFCs. International Journal of Hydrogen Energy, 36, 5557-5566. doi:10.1016/j.ijhydene. 2011.01.151

22. Sanson A., Pinasco P., Roncari E. (2008): Influence of pore formers on slurry composition and microstructure of tape cast supporting anodes for SOFCs. Journal of the European Ceramic Society, 28, 1221-1226. doi:10.1016/j. jeurceramsoc.2007.10.001
23. Jarot R., Muchtar A., Wan Daud W. R., Norhamidi M., Majlan E. H. (2011): Porous NiO-SDC Carbonates Composite Anode for LT-SOFC Applications Produced by Pressureless Sintering. Applied Mechanics and Materials, 52, 488-493. doi:10.4028/www.scientific.net/AMM. 52-54.488

24. Chen M., Kim B. H., Xu Q., Nam O. J., Ko J. H. (2008): Synthesis and performances of Ni-SDC cermets for ITSOFC anode. Journal of the European Ceramic Society, 28, 2947-2953. doi:10.1016/j.jeurceramsoc.2008.05.009

25. Huang J., Mao Z., Liu Z., Wang C. (2007): Development of novellow-temperatureSOFCswithco-ionic conducting SDCcarbonate composite electrolytes. Electrochemistry Communications, 9, 2601-2605. doi:10.1016/j.elecom.2007.07.036

26. Fergus J. W., Hui R., Li X., Wilkinson D. P., Zhang J. (2009). Solid oxide fuel cells: Materials properties and performance. CRC Press, Taylor \& Francis Group.

27. Oishi N., Atkinson A., Brandon N. P., Kilner J. A., Steele B. C. H. (2005): Fabrication of an Anode-Supported GadoliniumDoped Ceria Solid Oxide Fuel Cell and Its Operation at $550^{\circ} \mathrm{C}$. Journal of the American Ceramic Society, 88, 13941396. doi:10.1111/j.1551-2916.2005.00251.x

28. Kim M., Lee J., Han J.H. (2011): Fabrication of anode support for solid oxide fuel cell using zirconium hydroxide as a pore former. Journal of Power Sources, 196, 24752482. doi:10.1016/j.jpowsour.2010.10.109

29. Horri B. A., Selomulya C., Wang H. (2012): Characteristics of $\mathrm{Ni} / \mathrm{YSZ}$ ceramic anode prepared using carbon microspheres as a pore former. International Journal of Hydrogen Energy, 37, 15311-15319. doi:10.1016/j.ijhydene.2012. 07.108 